\title{
10: 103525817-103519877
}

National Cancer Institute

\section{Source}

National Cancer Institute. 10:103525817-103519877. NCI Thesaurus. Code C42267.

Physical location of FGF8_Gene 